\title{
34. INTERSTITIAL WATER CHEMISTRY DSDP LEG 23
}

\author{
B. J. Presley, R. R. Sims, and S. E. Feagley, Department of Oceanography, \\ Texas A\&M University, College Station, Texas
}

\section{INTRODUCTION AND PROCEDURES}

The Leg 23 pore water samples received at Texas A\&M had been shipped in the Manheim-type containers, that is, they had been heat sealed into sections of plastic pipe. Upon arrival here they were immediately refrigerated and were stored in that way until analytical work began in January 1973.

In response to verbal suggestions by Dr. Frank Manheim, the usual analytical program was not followed with these samples, rather the water was analyzed for a number of trace and minor constituents so that it could be compared to the well-known hot brine from the Red Sea.

The samples were transferred from the storage tubes to weighted plastic vials, which were then reweighed. In this way, the weight of each sample was determined. They ranged from less than 1 gram to somewhat over 3 grams, so that in all cases the analytical work was handicapped by the small sample size. Next, a volume of distilled-deionized water was added to each sample so that, based on shipboard salinity measurements, each would then have a total salinity about one-third that of normal seawater. The vials were weighed once more, and a wt/wt dilution factor was calculated for each sample.

Chloride was determined on these diluted samples using an automatic chloride titrator (Buchler Instruments). Bromide and ammonia were determined using slight modifications of procedures described earlier (Presley, 1971). The trace metals $\mathrm{Fe}, \mathrm{Mn}, \mathrm{Ni}, \mathrm{Cu}, \mathrm{Cd}$, and $\mathrm{Zn}$ were determined by atomic absorption, using one-third strength seawater as a blank. Lithium was determined by flame emission after the samples had been diluted a second time in order to more closely match them for chlorinity.

A precipitate of what appeared to be $\mathrm{Fe}_{2} \mathrm{O}_{3}$ could be seen inside the sample tube containing Sample 226-1-1. In order to correct for this obvious loss and other possible losses, all sample tubes were filled with $6 \mathrm{~N} \mathrm{HCl}$ and allowed to soak overnight. This $\mathrm{HCl}$ leach was then transferred with washing to a weighed vial and its weight was determined. All concentrations determined in this acid leach were then converted to an equivalent concentration in the original sample using the relative weights of the two solutions.

\section{RESULTS AND DISCUSSION}

All the analytical data are given in Table 1 . Note that samples from all of the sites occupied in the Red Sea were analyzed and the same determinations for two of the Leg 23 sites in the Indian Ocean were made. These Indian Ocean samples were chosen from very different geographic locations and from different sedimentological regimes in order to have something to compare the Red Sea samples with. This is especially important when dealing with trace constituents because there is great potential for sample contamination during the drilling operation and subsequent sample handling.

In this respect it is interesting to note that, except for the one sample from Site 226 and the bottom sample from Site 225 , the trace element concentrations are similar in the Red Sea and Indian Ocean. In addition to these two obvious exceptions, there is a definite indication of higher values, especially for $\mathrm{Mn}$ and $\mathrm{Zn}$, at depth at Site 228. Only the one sample from Site 226, from the hot brine area, gave values typical of the hot brine.

The $\mathrm{Cl}$ and $\mathrm{Br}$ values given in Table 1 show some interesting anomalies. Site 221 in the Indian Ocean gives a fairly normal $\mathrm{Cl} / \mathrm{Br}$ ratio, but an extremely low value for $\mathrm{Br}$, one checked several times, was found in the near surface sample at Site 222. This phenomenon has not been previously observed and there is no explanation for it.

The Red Sea sites gave the expected chloride enrichment at depth, with a smoothly increasing $\mathrm{Cl} / \mathrm{Br}$ ratio with depth at Sites 225 and 228 . This shows that the $\mathrm{NaCl}$, which is dissolving to give the $\mathrm{Cl}$-enriched water, is relatively free of $\mathrm{Br}$, an expected observation. Site 229 , near the entrance to the Red Sea showed much less enrichment of $\mathrm{Cl}$ with depth, and the $\mathrm{Cl} / \mathrm{Br}$ ratio is lower than that of seawater. This is indicative of a residual liquor enriched in $\mathrm{Br}$ by $\mathrm{NaCl}$ precipitation.

Lithium concentrations become greater with depth in all cases, and the highly saline samples from Sites 225 and 226 have very high lithium contents. When the $\mathrm{Li}$ values are ratioed against $\mathrm{Cl}$, however, the enrichments are seen to be less spectacular, being limited to an approximate twofold increase.

Ammonia concentrations were high in most of the samples, especially those from Site 229 , but no ammonia could be detected in the sample from Site 226, the hot brine sample.

\section{ACKNOWLEDGMENTS}

This work was supported by NSF Grant GA 20715.

\section{REFERENCE}

Presley, B. J., 1971. Techniques for analyzing interstitial water samples, Part I: Determination of selected minor and major inorganic constituents. In Winterer, E. L., Riedel, W. R., et al., Initial Reports of the Deep Sea Drilling Project, Volume VII: Washington (U. S. Government Printing Office), p. 1749. 
TABLE 1

Selected Constituents in Pore Water Squeezed from Leg 23 Samples

\begin{tabular}{|c|c|c|c|c|c|c|c|c|c|c|c|c|c|c|c|c|c|c|c|}
\hline \multirow[b]{2}{*}{ Sample } & \multirow{2}{*}{$\begin{array}{l}\text { Depth } \\
(\mathrm{m})\end{array}$} & \multirow{2}{*}{$\underset{(\mathrm{g} / \mathrm{kg})}{\mathrm{Cl}}$} & \multirow{2}{*}{$\begin{array}{c}\mathrm{Br} \\
(\mathrm{mg} / \mathrm{kg})\end{array}$} & \multirow[b]{2}{*}{$\mathrm{Cl} / \mathrm{Br}$} & \multirow{2}{*}{$\begin{array}{c}\mathrm{Li} \\
(\mathrm{mg} / \mathrm{kg})\end{array}$} & \multirow[b]{2}{*}{$\mathrm{Cl} / \mathrm{Li}$} & \multirow{2}{*}{$\underset{(\mathrm{mg} / \mathrm{kg})}{\mathrm{NH}_{3}}$} & \multicolumn{2}{|c|}{$\mathrm{Fe}(\mathrm{mg} / \mathrm{kg})$} & \multicolumn{2}{|c|}{$\mathrm{Mn}(\mathrm{mg} / \mathrm{kg})$} & \multicolumn{2}{|c|}{$\mathrm{Cu}(\mathrm{mg} / \mathrm{kg})$} & \multicolumn{2}{|c|}{$\mathrm{Ni}(\mathrm{mg} / \mathrm{kg})$} & \multicolumn{2}{|c|}{$\mathrm{Cd}(\mathrm{mg} / \mathrm{kg})$} & \multicolumn{2}{|c|}{$\mathrm{Zn}(\mathrm{mg} / \mathrm{kg})$} \\
\hline & & & & & & & & & & & & & B & & & & & & \\
\hline $221-6-1$ & 64 & 19.7 & 73 & 270 & 0.19 & 104 & 33.0 & $<0.2$ & 2.3 & $<0.5$ & $<0.1$ & 0.1 & 0.6 & - & $<0.1$ & 0.12 & 0.58 & 0.2 & 1.5 \\
\hline $221-12-3$ & 118 & 19.5 & 73 & 267 & 0.16 & 122 & 18.4 & $<0.2$ & 2.2 & 0.9 & $<0.1$ & 0.1 & $<0.1$ & - & $<0.1$ & 0.12 & $<0.05$ & 0.2 & 0.02 \\
\hline $221-17-2$ & 215 & 19.4 & 72 & 269 & 0.37 & 52 & 7.8 & $<0.2$ & 0.8 & 0.4 & $<0.1$ & 0.1 & $<0.1$ & - & $<0.1$ & 0.12 & $<0.05$ & 0.4 & 0.1 \\
\hline $222-1-4$ & 4 & 19.5 & 40 & 488 & 0.12 & 163 & 16.3 & $<0.2$ & 1.4 & 0.5 & $<0.1$ & 0.1 & $<0.1$ & - & $<0.1$ & 0.12 & $<0.05$ & 0.2 & $<0.01$ \\
\hline $222-3-3$ & 101 & 19.4 & 71 & 273 & 0.12 & 162 & 49.0 & $<0.2$ & 0.8 & 0.2 & $<0.1$ & 0.2 & $<0.1$ & - & $<0.1$ & 0.12 & $<0.05$ & 0.4 & $<0.01$ \\
\hline $222-22-5$ & 690 & 21.2 & 88 & 241 & 0.26 & 82 & 39.0 & $<0.2$ & 1.0 & 0.4 & $<0.1$ & 0.1 & $<0.1$ & - & $<0.1$ & 0.12 & $<0.05$ & 0.3 & $<0.01$ \\
\hline $225-3-4$ & 20 & 21.6 & 86 & 251 & 0.26 & 83 & 1.9 & 0.2 & 1.7 & 0.4 & $<0.1$ & $<0.1$ & $<0.1$ & 0.2 & $<0.1$ & $<0.05$ & $<0.05$ & 0.7 & 0.03 \\
\hline $225-8-3$ & 50 & 23.4 & 74 & 316 & 0.32 & 73 & 1.4 & 0.3 & 1.5 & 0.5 & $<0.1$ & $<0.1$ & 0.5 & 0.2 & $<0.1$ & $<0.05$ & $<0.05$ & 0.6 & 0.1 \\
\hline $225-13-6$ & 85 & 27.6 & 88 & 314 & 0.51 & 54 & 6.9 & 0.5 & 0.8 & 0.4 & $<0.1$ & 0.15 & $<0.1$ & 0.3 & $<0.1$ & 0.05 & $<0.05$ & 0.05 & $<0.01$ \\
\hline $225-28-1$ & 214 & 145.0 & 174 & 833 & 2.45 & 59 & 34.7 & 2.6 & - & 0.5 & $<0.1$ & 0.8 & - & 5.0 & - & 0.20 & - & 4.6 & - \\
\hline $226-1-1$ & 0.5 & 152.0 & 98 & 1551 & 3.12 & 49 & $<0.5$ & 33.0 & 19.0 & 70.0 & 0.2 & 0.45 & 0.1 & 2.0 & 0.15 & 0.20 & $<0.05$ & 15.0 & $<0.01$ \\
\hline $227-5-2$ & 38 & 24.6 & 80 & 308 & 0.35 & 70 & 5.3 & $<0.1$ & 1.7 & 0.7 & $<0.1$ & $<0.1$ & 0.2 & $<0.2$ & $<0.1$ & $<0.05$ & $<0.05$ & 0.9 & 0.4 \\
\hline $228-1-C C$ & 5 & 25.8 & 63 & 410 & 0.24 & 107 & $<0.5$ & 0.5 & 1.3 & 0.4 & $<0.1$ & $<0.1$ & 0.2 & 0.3 & 0.15 & $<0.05$ & $<0.05$ & 0.4 & 0.05 \\
\hline $228-5-3$ & 38 & 35.7 & 84 & 425 & 0.31 & 115 & 4.9 & 0.4 & 2.7 & 0.6 & $<0.1$ & 0.1 & $<0.1$ & $<0.2$ & $<0.1$ & $<0.05$ & $<0.05$ & 0.4 & $<0.01$ \\
\hline $228-16-5$ & 130 & 69.7 & 99 & 704 & 0.74 & 94 & 10.7 & 0.7 & 1.1 & 1.5 & $<0.1$ & 0.1 & $<0.1$ & 0.5 & $<0.1$ & $<0.05$ & $<0.05$ & 1.1 & $<0.01$ \\
\hline $228-19-2$ & 153 & 73.0 & 92 & 793 & 0.87 & 84 & 26.8 & 0.9 & 2.0 & 2.9 & $<0.1$ & 0.15 & $<0.1$ & 0.7 & $<0.1$ & $<0.05$ & $<0.05$ & 2.3 & $<0.01$ \\
\hline $228-21-2$ & 166 & 78.6 & 99 & 794 & 0.97 & 81 & 10.0 & 1.0 & 2.0 & 3.1 & $<0.1$ & 0.4 & 0.3 & 1.0 & $<0.1$ & 0.07 & $<0.05$ & 1.6 & $<0.01$ \\
\hline 229-1-CC & 9 & 21.8 & 117 & 186 & 0.27 & 81 & 5.7 & 0.5 & 1.8 & 0.4 & $<0.1$ & $<0.1$ & $<0.1$ & 0.2 & $<0.1$ & 0.05 & $<0.05$ & 0.5 & $<0.01$ \\
\hline $229 \mathrm{~A}-5-6$ & 73 & 23.4 & 105 & 223 & 0.22 & 106 & 70.9 & 0.3 & 2.1 & 0.4 & $<0.1$ & $<0.1$ & $<0.1$ & 0.5 & $<0.1$ & 0.05 & $<0.05$ & 0.5 & $<0.01$ \\
\hline $229-3-5$ & 100 & 22.5 & 90 & 250 & 0.26 & 87 & 48.1 & $<0.1$ & 0.9 & 0.6 & $<0.1$ & 0.8 & $<0.1$ & $<0.2$ & $<0.1$ & $<0.05$ & $<0.05$ & 1.0 & $<0.01$ \\
\hline $229 \mathrm{~A}-12-4$ & 155 & 24.0 & 113 & 212 & 0.32 & 75 & 78.2 & $<0.1$ & 1.1 & 0.5 & $<0.1$ & $<0.1$ & 0.2 & $<0.2$ & $<0.1$ & $<0.05$ & $<0.05$ & 0.5 & $<0.01$ \\
\hline $230-1-\mathrm{CC}$ & 9 & 31.9 & 75 & 425 & 0.24 & 133 & 35.1 & $<0.1$ & 0.9 & 0.4 & 0.1 & $<0.1$ & $<0.1$ & 0.2 & $<0.1$ & $<0.05$ & $<0.05$ & 0.4 & $<0.01$ \\
\hline \multicolumn{2}{|l|}{ Avg seawater } & 19.4 & 67 & 290 & 0.17 & 114 & - & - & - & - & - & - & - & - & - & - & - & - & - \\
\hline
\end{tabular}

Note: $A=$ concentration in water in tubes; $B=$ leaching from sample tubes. 